\title{
Yield Loss Assessment of Alternaria Leaf Blight of Rapeseed-Mustard under the Agro-Ecological Condition of West Bengal, India
}

\author{
Anuj Mamgain ${ }^{1}$, Mohan Kumar Biswas ${ }^{1 *}$ and Narottam Dey ${ }^{2}$ \\ ${ }^{1}$ Department of Plant Protection, Institute of Agriculture, Visva-Bharati, \\ Sriniketan-731236, West Bengal, India \\ ${ }^{2}$ Department of Biotechnology, Siksha Bhavana, Visva-Bharati, Santiniketan, \\ W.B., India, 731235, India \\ *Corresponding author
}

\begin{tabular}{|c|c|}
\hline & A B S T R A C T \\
\hline & \multirow{8}{*}{$\begin{array}{l}\text { Alternaria blight caused by Alternaria brassicae (Berk.) Sacc. has been reported as one of } \\
\text { the most serious threat to the production of rapeseed and mustard which is reflected in } \\
\text { various yield attributing factors eventually affecting the yield. The matter is of grave } \\
\text { concern as both the crops have economic importance and fetch return to the growers } \\
\text { merely on the basis of oil content. The present study was conducted in order to assess yield } \\
\text { loss of rapeseed and mustard with respect to various yield attributing factors in various } \\
\text { varieties under natural conditions. Differential response to Alternaria blight was observed } \\
\text { which clearly instigated a scope of using resistant host varieties against Alternaria blight. } \\
\text { Variety Kalyan ( } 393.83 \text { ) showed maximum number of pods per plant whereas the } \\
\text { minimum number was shown by Agrani ( } 232.87) \text {. Maximum number of seeds per pod } \\
\text { (14.43) was seen in variety Kalyan followed by Bhagirathi (13.56). Likewise the test } \\
\text { weight of } 1000 \text { seeds was found between } 4.07 \mathrm{~g} \text { (Agrani) to Kalyan ( } 8.70 \mathrm{~g} \text { ). Variety } \\
\text { Kalyan gave maximum yield ( } 1544.75 \mathrm{~kg} / \mathrm{ha} \text { ) while, it was minimum in case of variety } \\
\text { Agrani ( } 786.65 \mathrm{~kg} / \mathrm{ha} \text { ). The observations also show that Alternaria has a direct effect on } \\
\text { yield of rapeseed and mustard which was revealed by the fact that moderately resistant } \\
\text { varieties had more yield (w.r.t. yield and other yield attributing factors) as compared to } \\
\text { highly susceptible varieties. The pattern of yield of various cultivars gave almost similar } \\
\text { results to prior studies based on different epidemiological parameters thus, showing the } \\
\text { potential of forming a baseline for determining the reaction group of the } \\
\text { varieties/genotypes against Alternaria blight under natural conditions. }\end{array}$} \\
\hline & \\
\hline $\begin{array}{l}\text { Alternaria blight, } \\
\text { Yield loss }\end{array}$ & \\
\hline $\begin{array}{l}\text { Yield loss } \\
\text { assessment, } \\
\text { Rapeseed -mustard, }\end{array}$ & \\
\hline $\begin{array}{l}\text { Alternaria } \\
\text { brassicae. }\end{array}$ & \\
\hline Article Info & \\
\hline $\begin{array}{l}\text { Accepted: } \\
\text { 24 February } 2017 \\
\text { Available Online: } \\
\text { 10 March } 2017\end{array}$ & \\
\hline & \\
\hline
\end{tabular}

\section{Introduction}

Alternaria blight caused by Alternaria brassicae (Berk.) Sacc. has been recognized as a potentially destructive disease of many Brassicaceae crops throughout the world. Among the widely affected hosts, its effect on oilseeds especially rapeseed-mustard (collectively called oilseed Brassicas) can reach up to an extent of more than fifty percent (Mamgain et al., 2014). In oilseed Brassicas, the symptoms of disease caused by A. brassicae appear primarily in the seedling stage on cotyledons and hypocotyls in the form of small light brown lesions which at adult stage affect leaves, leaf petiole, stem, inflorescence, siliquae and seeds (Jung et al., 2002, Prasad and Lallu, 2006). The infection 
of Alternaria blight on leaves and siliquae reduces the photosynthetic area drastically. The phase of infection on siliquae adversely affects the normal seed development, seed weight, seed colour, percent oil content in seed and the quality of seed (Meena, 2010). Thus, the damaged seeds usually show both internal and external presence of fungus (Srivastava et al., 2011). Deep lesions of Brassica pods increase the percentage of seed infection and decrease pod length, seeds per pod, test weight, percentage seed germination and percent oil content (Chahal and Kang, 1979; Tripathi et al., 1987). The objectives of the present investigation were to determine the effect of varying levels of Alternaria blight severity on yield components of rapeseed-mustard with respect to various yield attributing factors like total pods per plant, number of seeds per pod, test weight (weight of 1000 seeds) and seed yield under conditions typical of undulating red and lateritic zone of West Bengal to get an acquaintance regarding the direct impact of Alternaria blight on the yield of rapeseed and mustard.

\section{Materials and Methods}

Assessment of yield losses by Alternaria blight was done at Agricultural Farm, Palli Siksha Bhavana Agricultural Research farm, Sriniketan, Birbhum, West Bengal for two consecutive years i.e. 2011-12 and 2012-13 using different varieties of rapeseed and mustard viz. Varuna (T-59), Sarma (RW-8559), Seeta (B-85), Panchali (TWC-3), Agrani (B-54), Binoy (B-9), Jhumka (NC-1), Bhagirathi (RW-351) and Kalyan (WBB-1). The field experiments were carried out in randomized block design (RBD) with three replications. The size of the experimental plots was $5 \times 3 \mathrm{~m}^{-2}$. To record the initial infection of blight disease, the plots were examined properly after sowing. Incidence of Alternaria blight of mustard was recorded at an interval of ten days after appearance of first disease symptom and it was continued up to the senescence of crop. The yield attributing factors like total pods per plant, number of seeds per pod, test weight (weight of 1000 seeds) and seed yield were carefully examined.

\section{Results and Discussion}

Since mustard and rapeseed (or oilseed brassicas) are a crop of economic importance, therefore, the effect of the disease on the yield components of the crop was also studied. The different yield components/ yield attributing factors studied are discussed below in table 1 .

\section{Total pods per plant}

From Table 1, it can be concluded that none of the varieties were significantly at par when the data was pooled on a cumulative basis for two years i.e. 2011-12 and 2012-13 for total pods per plant. Variety Kalyan (393.83) showed maximum number of pods per plant whereas the minimum number was shown by Agrani (232.87). The data clearly indicated that there is a statistical similarity between the varieties in terms of number of pods per plant owing to the differential yield of studied varieties. The findings clearly enlarged the vision regarding different yield of the studied varieties when subjected to Alternaria stress and pictorial representation of which has been presented in Fig. 1.

\section{Number of seeds per pod}

Number of seeds per pod, a yield factor was also assessed as a yield component which directly reflects the increase or decrease in yield (Table 1). On studying pooled value for the data set pertaining over two years, it was found that maximum number (14.43) was seen in Kalyan. 
Table.1 Effect of Alternaria leaf blight on the yield components of different rapeseed-mustard varieties grown under field conditions

\begin{tabular}{|c|c|c|c|c|c|c|c|c|c|c|c|c|}
\hline \multirow[t]{2}{*}{ Varieties } & \multicolumn{3}{|c|}{ Total pods per plant } & \multicolumn{3}{|c|}{ Number of seeds per pod } & \multicolumn{3}{|c|}{ Test Weight (g) } & \multicolumn{3}{|c|}{ Seed Yield (kg/ha) } \\
\hline & $\begin{array}{c}2011- \\
12\end{array}$ & $\begin{array}{c}2012- \\
13\end{array}$ & Pooled & $\begin{array}{c}\text { 2011- } \\
12\end{array}$ & $\begin{array}{c}2012- \\
13\end{array}$ & Pooled & 2011-12 & 2012-13 & Pooled & $\begin{array}{c}2011- \\
12\end{array}$ & $\begin{array}{c}2012- \\
13\end{array}$ & Pooled \\
\hline Varuna & 255.75 & 250.65 & $253.20^{\mathrm{g}}$ & 10.24 & 9.14 & $9.69^{d}$ & 4.75 & 4.55 & $4.65^{\mathrm{de}}$ & 815.7 & 810.6 & $813.15^{\mathrm{f}}$ \\
\hline Sarma & 315.92 & 310.82 & $313.37^{\mathrm{e}}$ & 12.21 & 11.11 & $11.66^{\mathrm{c}}$ & 5.78 & 5.58 & $5.68^{\mathrm{c}}$ & 1234.1 & 1229.1 & $1231.60^{\mathrm{d}}$ \\
\hline Seeta & 323.46 & 318.36 & $320.91^{\mathrm{d}}$ & 12.45 & 11.35 & $11.90^{\mathrm{c}}$ & 5.64 & 5.44 & $5.54^{\mathrm{c}}$ & 1217.3 & 1212.2 & $1214.75^{\mathrm{e}}$ \\
\hline Panchali & 239.48 & 234.38 & $236.93^{h}$ & 9.38 & 8.28 & $8.83^{\mathrm{e}}$ & 4.38 & 4.18 & $4.28^{\mathrm{ef}}$ & 799.4 & 794.3 & $796.85^{\mathrm{h}}$ \\
\hline Agrani & 235.42 & 230.32 & $232.87^{\mathrm{i}}$ & 9.24 & 8.14 & $8.69^{e}$ & 4.12 & 4.02 & $4.07^{\mathrm{f}}$ & 789.2 & 784.1 & $786.65^{\mathrm{i}}$ \\
\hline B-9 & 260.45 & 255.35 & $257.90^{f}$ & 10.33 & 9.23 & $9.78^{\mathrm{d}}$ & 4.94 & 4.74 & $4.84^{\mathrm{d}}$ & 811.1 & 805.1 & $808.10^{\mathrm{g}}$ \\
\hline Jhumka & 329.42 & 324.32 & $326.87^{\mathrm{c}}$ & 12.75 & 11.65 & $12.20^{\mathrm{c}}$ & 5.92 & 5.72 & $5.82^{c}$ & 1237.6 & 1232.5 & $1235.05^{c}$ \\
\hline Bhagirathi & 380.78 & 375.68 & $378.23^{b}$ & 14.10 & 13.01 & $13.56^{\mathrm{b}}$ & 8.24 & 8.12 & $8.18^{\mathrm{b}}$ & 1517.9 & 1512.8 & $1515.35^{b}$ \\
\hline Kalyan & 396.38 & 391.28 & $393.83^{\mathrm{a}}$ & 14.98 & 13.88 & $14.43^{\mathrm{a}}$ & 8.75 & 8.65 & $8.70^{\mathrm{a}}$ & 1547.3 & 1542.2 & $1544.75^{\mathrm{a}}$ \\
\hline $\operatorname{SEM}( \pm)$ & 0.79 & 0.50 & 0.47 & 0.38 & 0.26 & 0.23 & 0.23 & 0.22 & 0.16 & 0.62 & 0.67 & 0.46 \\
\hline $\mathrm{CD}$ at $5 \%$ & 2.37 & 1.51 & 1.35 & 1.13 & 0.78 & 0.66 & 0.70 & 0.67 & 0.46 & 1.85 & 2.02 & 1.31 \\
\hline
\end{tabular}

Note: Treatments with similar alphabetical letters are statistically at par at $\mathrm{p}=0.05$ 
Fig.1 Effect of Alternaria leaf blight on total pods /plants of different mustard and rapeseed varieties under natural conditions

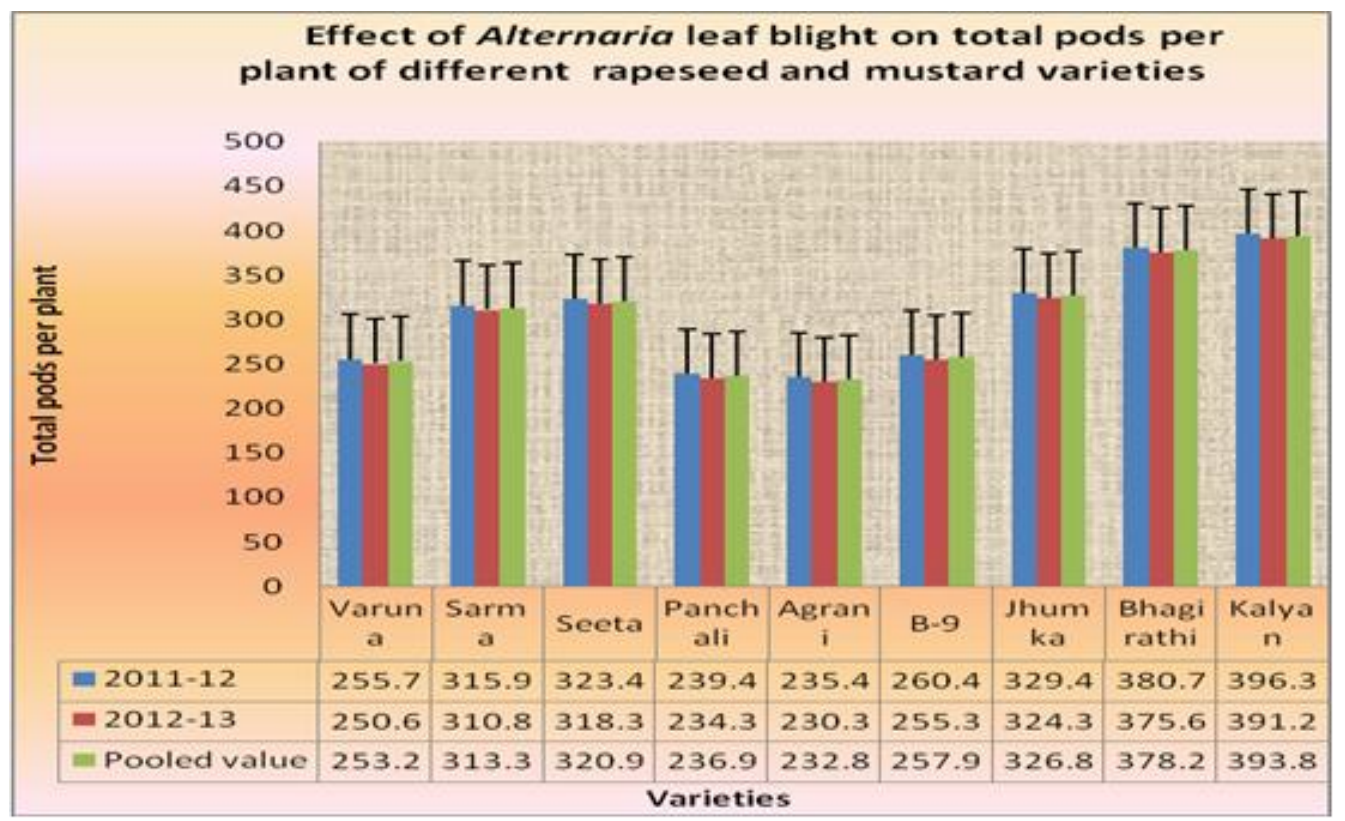

Fig.2 Effect of Alternaria blight on number of seeds per pod of different rapeseed and mustard varieties under natural conditions

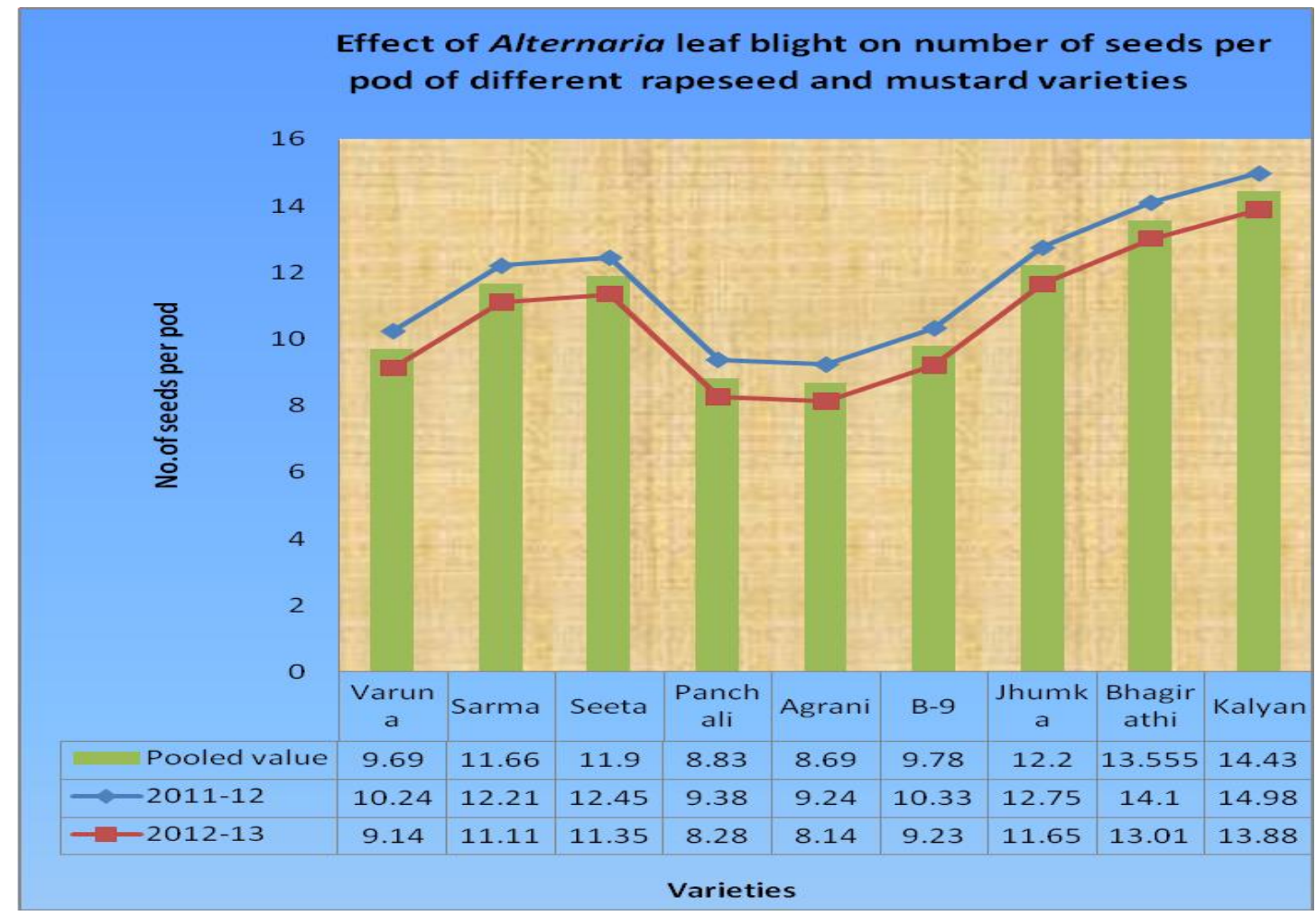


Fig.3 Effect of Alternaria blight on test weight of different mustard and rapeseed varieties under natural conditions

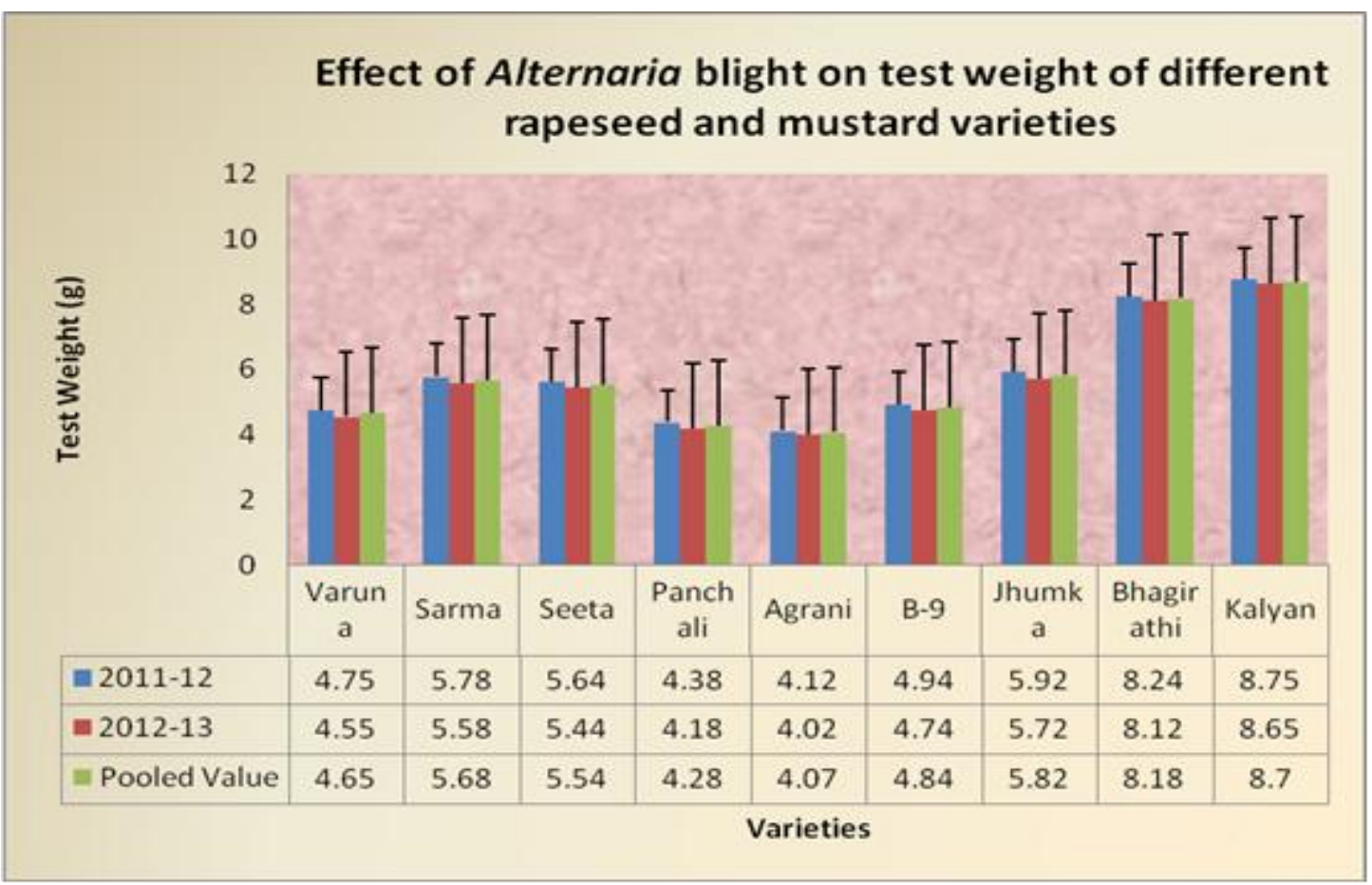

Fig.4 Effect of Alternaria blight on seed yield of different rapeseed and mustard varieties under natural conditions

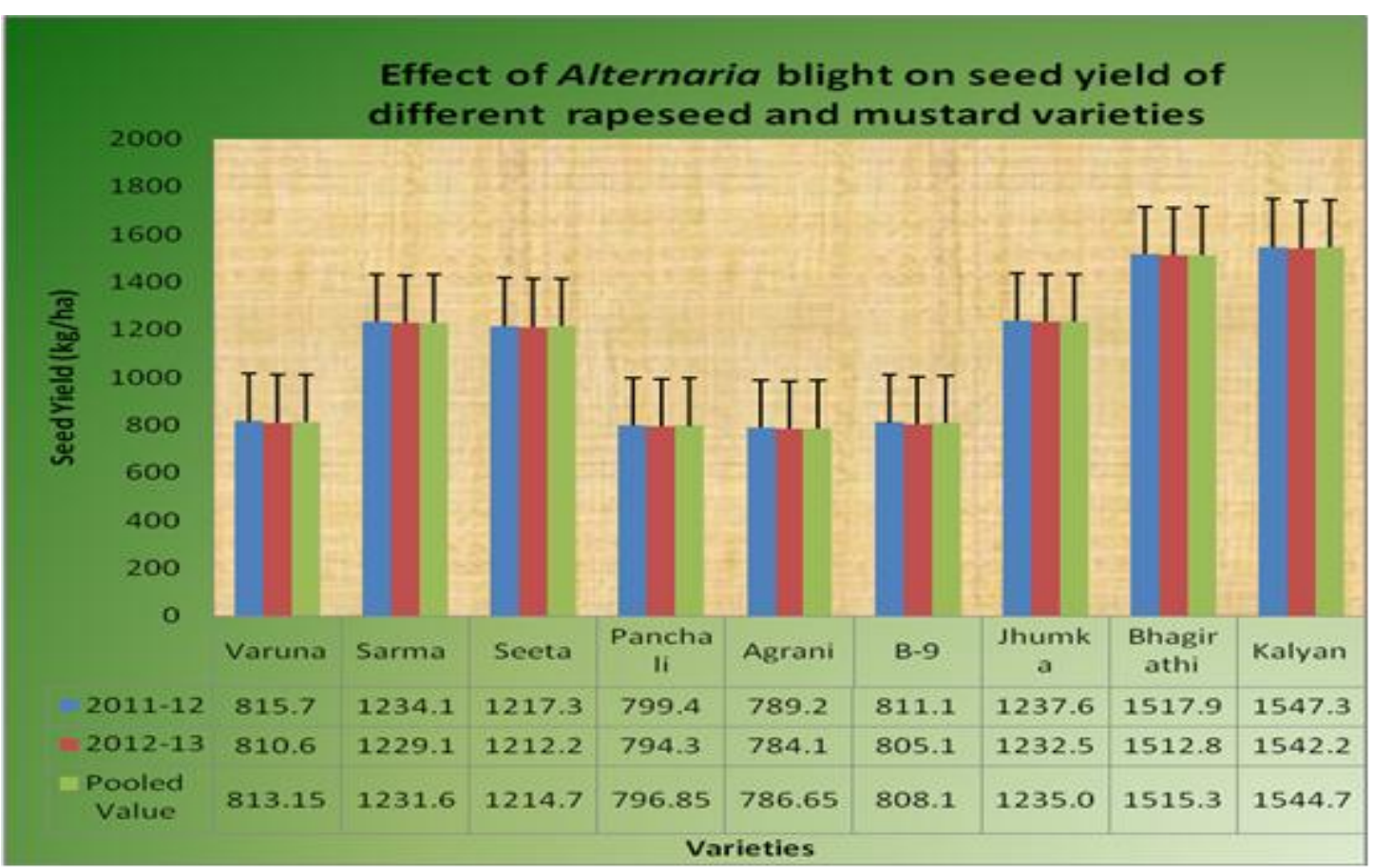


Bhagirathi (13.56) followed Kalyan in being second variety for the yield component. Sarma (11.66), Seeta (11.90) and Jhumka (12.20) showed significantly at par results and followed Kalyan. Varuna (9.69) and B-9 (9.78) showed similar number of seeds per pod statistically. Finally Agrani (8.69) and Panchali (8.83) showed statistically at par results in having least number of seeds per pod. The study clearly demarcate significant differences among varieties in relation to number of seeds per pod which is a vital yield component keeping in view the economical aspect of oilseed Brasssicas (Fig. 2).

\section{0 seed weight (test weight)}

From Table 1, depicting effect of natural incidence on test weight of the studied varieties, it was found that Kalyan (8.70g) showed maximum test weight which was significantly different from rest of the varieties. Bhagirathi $(8.18 \mathrm{~g})$ followed Kalyan and was then followed by Jhumka (5.82g), Sarma (5.68g) and Seeta (5.54g) which showed significantly at par results. B-9 (4.84g) and Varuna (4.65g) showed similar results statistically while Panchali (4.28g) was statistically similar to that of Varuna $(4.65 \mathrm{~g})$, Agrani (4.07g) was the variety found to be associated with the least test weight and thus was the variety found to be most adversely affected by Alternaria blight in terms of test weight. The pictorial representation has been presented of the study has been provided in figure 3 .

\section{Seed yield}

From table 1 \& Fig. 4 depicting effect of Alternaria blight on seed yield, significant differences were observed among all varieties (based on pooled values). The mean value was found to be $1105.14 \mathrm{~kg} / \mathrm{ha}$ with values ranging between $786.65 \mathrm{~kg} / \mathrm{ha}$ to $1544.75 \mathrm{~kg} / \mathrm{ha}$. The minimum value was found to be associated with Agrani (786.65 $\mathrm{kg} / \mathrm{ha})$ while the maximum was associated with Kalyan $(1544.75 \mathrm{~kg} / \mathrm{ha})$. The data clearly indicated that sowing of varieties plays a crucial and significant role on seed yield of rapeseed and mustard which is the characteristic of a particular variety. Hence varieties with more seed yield should be prioritized over other varieties.

The study provided elementary idea regarding the differential behaviour of the studied rapeseed-mustard varieties towards Alternaria blight. The studied rapeseed-mustard varieties on the basis of host resistance response against Alternaria blight under natural conditions were segregated into moderately resistant, moderately susceptible, susceptible and highly susceptible groups by Mamgain et $a l$., (2014). From the studies, it was found that varieties Varuna, Panchali, Agrani and B-9 came under 'Highly Susceptible' reaction group' while Bhagirathi and Kalyan came under 'Moderately Resistant' group. Apart from these extreme reaction groups of oilseed Brassicas varieties, Seeta and Jhumka came under 'Moderately Susceptible' while Sarma under 'Susceptible' variety against Alternaria blight. The observations also show that Alternaria has a direct effect on yield of rapeseed and mustard which is revealed by the fact that moderately resistant varieties have more yield (w.r.t. yield and other yield attributing factors) as compared to highly susceptible varieties. This clearly shows that loss assessment w.r.t. yield attributing factors is a direct measure of Alternaria blight impact on yield loss.

In conclusions Alternaria blight is a potentially devastating disease that could seriously affect rapeseed and mustard production as the disease has a direct impact on total pods per plant, number of seeds per pod, test weight and seed yield. The reduction in seed yield is in particular a matter of grave 
concern as the growers receive a price premium based on oil content of rapeseed and mustard. This seed yield is in turn a direct measure of oil content in these crops. Control of the disease is also critical due to the seed borne nature of the pathogen (Herr and Lipps, 1982; Carson, 1985). The drastic effects of the disease can be visualized on the various yield components of rapeseed and mustard which are reflected in the overall seed yield. However host resistance of some genotypes of rapeseed and mustard against Alternaria blight was also observed during the study. The development and exploitation of genetic resistance in rapeseed and mustard is probably the best way to reduce the threat of Alternaria blight to rapeseed-mustard production.

\section{References}

Carson, M.L. 1985. Epidemiology and yield losses associated with Alternaria blight of sunflower. Phytopathol., 75: 11511156.

Chahal, A.S. and Kang, M.S. 1979a. Different levels of Alternaria Blight in relation to grain yield in brown sarson. Indian $J$. Mycol. Plant Pathol., 9: 260-261.

Chahal, A.S. and Kang, M.S. 1979b. Some aspects of seed-born infection of Alternaria brassica in rape and mustard cultivars in the Punjab. India J. Mycol. Pl. Path., 9: 51-52.

Herr, L.J. and Lipps, P.E. 1982. Alternaria helianthi in Ohio. Plant Dis., 66: 509512.

Jung, D.S., Na, Y.J. and Ryu, K.H. 2002. Phyolgenic analysis of Alternaria brassicicola producing bioactive metabolites. J. Microbiol., 40: 289-294.

Mamgain, A., Biswas, M.K. and Dey, N. 2014. Host Resistance of Genotypes of Rapeseed and Mustard against Alternaria blight Under the Agroecological Conditions of Undulating Red and Lateritic Belt of West Bengal. Int. J. Adv. Res., 2(10): 989-996.

Meena, P.D., Awasthi, R.P., Chattopadhyay, C., Kolte, S.J. and Kumar, A. 2010. J. Oilseed Brassica, 1: 1-11.

Prasad, R. and Lallu. 2006. Management of Alternaria blight of mustard with combination of chemicals and botanicals. Ann. Pl. Protec. Sci., 14(2): 400-403.

Srivastava, M., Gupta, S.K., Saxena, A.P., Shittu, L.A.J. and Gupta, S.K. 2011. A Review of occurrence of fungal pathogens on significant Brassicaceous Vegetable Crops and their control measures. Asian J. Agri. Sci., 3(2): 7079.

Tripathi, N.N., Saharan, G.S., Koushik, C.D., Kavshi, R.J.C. and Gupta, P.P. 1987. Magnitude of losses in yield and management of Alternaria blight of rapeseed and mustard. Haryana Agric. Univ. Res. J., 17: 14-18.

\section{How to cite this article:}

Anuj Mamgain, Mohan Kumar Biswas and Narottam Dey. 2017. Yield Loss Assessment of Alternaria Leaf Blight of Rapeseed-Mustard under the Agro-Ecological Condition of West Bengal. Int.J.Curr.Microbiol.App.Sci. 6(3): 2369-2375. doi: http://doi.org/10.20546/ijcmas.2017.603.271 